\title{
Strategi Mengintegrasikan Kurikulum Pondok dan Sekolah dalam Meningkatkan Prestasi Siswa SMP Mambaus Sholihin
}

\author{
Umi Nahdiyah \\ Universitas Nadlatul Ulama Blitar, Indonesia \\ Email: nahdiyahumi94@gmail.com
}

\begin{tabular}{l} 
Tersedia Online di \\
\hline http://www.jurnal.unublitar.ac.id/ \\
index.php/briliant \\
\hline \\
\hline Sejarah Artikel \\
\hline Diterima pada 12 Maret 2020 \\
Disetujui pada 20 April 2020 \\
Dipublikasikan pada 30 Mei 2020 \\
Hal. 362-368
\end{tabular}

\section{Kata Kunci:}

Strategi; Integrasi Kurikulum;

Prestasi

\section{DOI:}

http://dx.doi.org/10.28926/briliant .$v 3 \mathrm{i} 4.450$

\begin{abstract}
Abstrak: Tujuan penelitian ini adalah untuk mengetahui Strategi mengintegrasikan kurikulum sekolah dan pondok pesantren dan dalam meningkatkan prestasi siswa konsep serta hasil perpaduan kurikulum pondok pesantren dan sekolah SMP Mambaus Sholihin. Metode penelitian kualitatif di pakai dalam penelitian ini dengan (field research) penelitian lapangan, dengan studi kasus yang dipakai untuk pendekatannya, termasuk penelitian deskriptif. Hasil penelitian yang diperoleh Pertama, konsep integrasi kurikulum melalui penggabungan mata yakni Nahwu dan Sorof itu di masukkan kedalam kurikulum sekolah. Kedua, hasil dari integrasi kurikulum telah cukup terlihat dari output atau lulusan peserta didiknya. Prestasi yang diperoleh oleh siswa baik akademik maupun non akademik semakin meningkat.
\end{abstract}

\section{PENDAHULUAN}

Dewasa ini di pesantren pendidikan cukup menjadi pilihan dan perhatian dari masyarakat, dan hal ini berbeda dengan tahun silam. Paradigma masyarakat berbeda sangat jauh. Masyarakat sekarang lebih banyak memilih pendidikan untuk anaknya yang kental dengan agama, seperti pondok pesantren dengan lembaga formal. Sekolah asrama adalah sekolah yang di sediakan untuk tempat mendidik siswa-siswanya sekaligus tempat tinggal selama jarak waktu yang ditentukan. (Hendriyenti, 2014).

Sekolah asrama merupakan sekolah yang di tambahkan asrama, guru dan siswa serta orang yang mengelola lembaga mukim di asrama yang berada di satu lingkungan lembaga dalam jarak waktu yang ditentukan, satu semester biasanya yang di selingi libur sebulan sampai menyelesaikan pendidikannya. Berjalannya dengan kemajuan zaman, kurikulum pada lembaga yang menerapkan sistem sekolah asrama dirancang dengan orientasi masa depan. Dalam menerapkannya dengan berbasis IT, sebagai pemanfaatan perpustakaan menggunakan internet, sebagai sumber belajar yang efektif, sumber utama informasi, sumber yang relevan dengan materi pelajaran dengan penayangan film, dan laboratorium komputer dan penggunaan laboratorium bahasa yang intensif. Dibanding sekolah lainnya, kurikulum yang disajikan kepada siswapun sedikit berbeda.

Dalam menghadapi tantangan modernisasi, sekolah yang berbasis asrama mempunyai strategi pendidikan Islam. Dengan sistem boarding school prinsip dasar pendidikan Islam, berupaya mengintegrasikan kauniyah (ayat tanda 
kebesaran Allah dalam alam semesta) dengan ayat qauliyah (ayat al-Qur'an), ilmu serta iman, aspek ruhiyah serta fikriyah dengan jasadiyah yang berhubungan dengan sosial siswa yang di terapkan dalam pembelajaran. Baik di sekolah maupun di asrama dalam kegiatan ekstrakurikuler, ustadz-ustadzah telah memantau selama 24 jam. Pada semua aktivitas siswa yang diprogramkan merupakan letak keserasian sistem boardingnya, dijadwalkan serta diatur secara jelas. Serta muatan nilai-nilai moral merupakan sarat aturan kelembagaannya.

Secara global pendidikan Islam mengarah pada pergerakan dari pemeliharaan nilai-nilai dan ajaran agama Islam. Terkait upaya peningkatan mutu akademik yang merupakan pemenuhan kebutuhan pemerintah dan lembagalembaga. Mata pelajaran pendidikan Agama Islam idealnya bisa mendasari pendidikan-pendidikan lain. Dalam membentuk watak serta kepribadian peserta didik, PAI seharusnya mendapat waktu yang proporsional, demikian halnya dalam membangun moral bangsa (nation character building) serta upaya peningkatan mutu pendidikan, PAI harus dijadikan tolak ukur, (Muhammad Alim, 2006).

Peran orang tua sangat penting dalam membina dan membimbing moral remaja demi terciptanya masa depan yang bermoral. Moral remaja sangat tergantung bagaimana orang tua dalam membina dan membimbing.

Menurut Hasan Manshur, ada beberapa cara yang bias dilakukan orangtua dalam membimbing remaja dan anak antara lain yaitu dengan kasih sayang yang diberikan, memberikan keteladanan yang baik serta contoh-contoh sikap moral terhadap anak-anaknya, karena tolak ukur perilaku dan sikap bagi anak adalah orang tua (Hasan Mansur, 2002). Impelementasi pendidikan lebih terpantau dengan adanya program boarding school, karena semua kegiatan siswa telah terpantau 24 jam serta terjadwal. Pendidikan kemandirian ditekankan pada Sistem boarding school lebih mudah terlaksana. Aplikasi pembelajaran tidak hanya berlangsung di asrama saja implementasi pendidikan, namun juga terjadi sinkronisasi antara kegiatan di sekolah dengan pendidikan diasrama. Sehingga, metodologi pendidikan akan lebih terarah dan efektif yang berwujud keteladanan dan pengajaran (Donie Koesoema A, 2007).

Dengan adanya perpaduan lembaga formal dengan pondok pesantren dalam lingkungan pesantren secara langsung maupun tidak langsung telah memberi kontribusi untuk memajukan dan memodernisasikan pendidikan di pesantren yang apda awalnya hanya terpaku pada pendidikan keagamaan. Selain itu pesantren dulunya di pandang sebelah mata oleh sebagian orang kini telah berbalik arah dengan menamakan lembaga pendidikan tersebut sebagai sekolah plus di mana selain mempelajari pendidikan agama juga memberikan materi umum sehingga para lulusan pesantren tidak hanya terbatas pada ruang lingkup keagamaan akan tetapi juga mampu ikut serta dalam arus modernisasi. Di dalam sekolah yang bernaung dibawah yayasan pesantren pendidikan agama tidak menjadi masalah. Sebab kurikulum yang disusun disekolah diadaptasi dengan lingkungan santri dan ruh pesantren. Tetapi bagi sekolah umum meskipun agama disisipkan tapi porsinya sangat sedikit dan terkesan hanya membebani aspek kognitif saja. Karena internalisasi afektif (nilai) tidak tertata secara baik. Upaya untuk memaksimalkan proporsi pendidikan umum dan agama di pesantren memunculkan upaya memadukan aspek-aspek kurikulum yaitu ke dalam sebuah kurikulum yang integratif. Pola ini sebagai langkah dalam meningkatkan kualitas pendidikan 
sekolah dengan cara memadukan pesantren tradisional. Sehingga akan memperbanyak pengetahuan umum dan agama.

Gambaran konkrit permasalahan terjadi di SMP 2 Mabaus Sholihin yang mana kedua lembaga ini diterapkan sistem pendidikan asrama bagi peserta didik yang menempuh pendidikan di lembaga ini. Penerapan sistem tersebut adalah sebagai salah satu sistem pembelajaran dan pengembangan diri bagi siswa-siswi. Adapun klasifikasi sistem tersebut terdiri dari bimbingan membaca kitab kuning, bimbingan baca tulis al-Qur'an (BTA), bimbingan kitabah 4 bahasa (Indonesia, Inggris, Arab, serta Jawa), bimbingan belajar pelajaran UN, bimbingan pendalaman materi keagamaan, bimbingan bahasa Inggris, dan bahasa Arab, serta ba'da subuh yaitu Muhadatsah/ speaking bahasa Arab dan bahasa Inggris, juga pengembangan Ilmu Teknologi (IT). Dalam bidang akademis pun, SMP Mambaus Sholihin seringkali mendapat kejuaraan, baik itu kejuaraan bidang akademik mapun non akademik. Prestasi yang cukup mencolok ialah Juara internasional Robotik game in japan, Juara Cerdas Cermat al-Qur'an, Juara Pidato Bahasa Arab, Juara Pidato Bahasa Inggris, Juara Ta'dimul Qisos, juara Seni pagar Nusa, juara 1 SBQ, juara MTQ, juara Qira'.

Untuk itulah dalam penelitian kali ini peneliti tertarik untuk mengkaji dan meneliti lebih mendalam. Bagaimana Strategi mengintegrasikan kurikulum sekolah dan pondok pesantren dalam meningkatkan prestasi siswa. Mengacu pada hal itu peneliti mencoba meneliti tentang Strategi Mengintegrasikan Kurikulum Pondok dan Sekolah dalam Meningkatkan Prestasi Siswa SMP Mambaus Sholihin.

\section{METODE}

Jenis metode penelitian ini kualitatif (field qualitatif research), karena peneliti melakukan penggalian data berdasarkan teori secara alamiah atau tanpa rekayasa. Dalam penelitian ini, peneliti mengkaji tentang Strategi Mengintegrasikan Kurikulum Pondok dan Sekolah dalam Meningkatkan Prestasi Siswa SMP Mambaus Sholihin. Rancangan yang digunakan dalam penelitian ini adalah studi kasus. Jenis penelitiannya adalah penelitian lapangan (field research). Adapun sumber data diperoleh melalui dua cara yaitu sumber data primer dan sumber data sekunder.

\section{HASIL}

Berdasarkan uraian di atas, mengenai Strategi Mengintegrasikan Kurikulum Pondok dan Sekolah dalam Meningkatkan Prestasi Siswa SMP Mambaus Sholihin yaitu di SMP Mambaus Sholihin. maka diperoleh temuan sebagai berikut:

1. Konsep mengintegrasikan kurikulum pondok pesantren dan sekolah

a. Konsep integrasi kurikulumnya ada dua, 1) kurikulum pondok atau kurikulum salafi, dan 2) kurikulum sekolah. Dilembaga ini semua santri wajib bermukim di pondok pesantren serta pembelajaran terpantau selama 24 jam. Dalam pembelajaran pendidik harus mempersiapkan RPP dan Silabus sebagai pedoman dalam pembelajaran yang dibuat di awal tahun ajaran baru. Ketepaduan antara pondok pesantren dengan sekolah, yakni keterpaduan mata pelajaran di pondok dengan sekolah, seperti mata pelajaran Nahwu, pelajaran Sorof itu di masukkan kedalam kurikulum sekolah. Ketika pelaksanaan ujian pun siswa-siswi juga melaksanakan ujian mata pelajaran Nahwu, sorof seperti pelajaran yang 
lainnya. Selain itu, Siswa-siswi kelas IX diwajibkan hafal imriti sebagai syarat kelulusannya. Konsep yang dilakukan guru, setiap awal tahun setiap guru menyusun rencana pelaksanaan pembelajaran yang disesuaikan dengan kurikulum nasional. Serta ditambah dengan kurikulum khas pondok pesantren. Dalam perencanaan ini, Kepala Sekolah membimbing para guru untuk menyusun RPP sesuai silabus yang ada. Dalam merencanakan materi guru menyesuaikan dengan kondisi siswa dan lingungan sekitar. Langkah-langkah pembelajaran yang pertama kali guru lakukan adalah merencanakan berdasarkan materi, sarana prasarana dan keadaan siswa. Perencanaan dilakukan sebelum kegiatan belajar mengajar berdasarkan materi.

b. Pembagian alokasi waktu disesuaikan dengan jumlah mata pelajaran yang ada, disesuaikan dengan kalender pendidikan dan pekan efektif. Pendidik harus kreatif dalam menentukan metode penyampaian ke peserta didik supaya proses pembelajaran menarik.

c. Materi pembelajaran di pondok pesantren seperti pembiasaan yang berhubungan dengan materi kehidupan sehari-hari. Dalam konsep pembelajarannya dilakukan dengan menanamkan pembiasaan dalam kehidupan sehari-hari siswa. Jadi konsep perencanaan pembelajaran yan dilaksanakan tentang bagaimana siswa menjalankan kegiatannya dalam kehidupan sehari-hari, baik di pondok pesantren maupun di sekolah, bagaimana siswa beradaptasi dengan siswa yang lain, bagaimana siswa dalam menyelesaikan konflik, bagaimana siswa berbagi dengan siswa yang lain, dan bagaimana siswa melakukan control terhadap ibadah yang dilakukan terutama ibadah shalat. Pembelajarannya berkaitan dengan pembiasaan siswa akan kegiatan yang dilakukan siswa tersebut.

2. Hasil dari mengintegrasikan kurikulum pondok pesantren dan sekolah

a. Hasil integrasi kurikulum di SMP Mambaus Sholihin telah cukup terlihat dari output atau lulusan peserta didiknya. Tampak sekali banyak prestasi yang diperoleh siswa-siswa dalam berbagai perlombaan. Baik prestasi akademik maupun non akademik. Sebagai syarat kelulusannya siswa-siswi kelas IX wajib hafal imriti. Dalam proses pembalajarannya dilakukan dengan mengevaluasi kegiatan yang ada. Evaluasi yang dilakukan oleh guru, dilakukan pada saat penyampaian materi pembelajaran. Sedangkan untuk evaluasi yang dilakukan Kepala Sekolah terkait dengan kinerja guru dalam melakukan proses belajar mengajar.

b. Evaluasi yang dilakukan guru adalah evaluasi hasil belajar yang pada akhirnya nilai dimasukkan raport. Untuk jenis evaluasi yang digunakan uyaitu evaluasi kognitif dan evaluasi afektif. Evaluasi kognitif, menyangkut pada penugasan materi dan bagaimana siswa menangkap materi tersebut. Penilaian kognitif dilakukan dengan cara membuat soal-soal ualngan. Sedangkan penilaian afektif merupakan penilaian yang menyangkut pada perilaku dan sikap siswa, baik ketika siswa melakukan diskusi maupun sikap siswa terhadap bersihan dan kerapian kelas. Untuk jenis penilaiannya tergantung dari metode dan tujuan pembelajaran. Evaluasi yang dilakukan Kepala Sekolah adalah dengan 
cara supervise yang diadakan setiap semester dua kali untuk melihat persiapan mengajar guru dan pelaksanaannya.

c. Evaluasi pembelajaran dilakukan oleh seluruh Pamong pondok pesantren adalah semua pamong pondok pesantren menyerahkan hasil evaluasi tersebut ke BK dari seluruh pondok pesantren. Jadi BK inilah sentral dari semua evaluasi yang telah dilakukan. BK tidak menjadi pamong pondok pesantren, karena BK merupakan bimbingan untuk seluruh siswa di dalam pondok pesantren maupun di sekolah, jadi untuk BK 24 jam. Hasil dari evaluasi tersebut dilaporkan kepada guru BK, pamong pondok pesantren, wali kelas, dan pimpinan. Hasil penilaian tersebut digunakan untuk menilai kepribadian setiap anak diambil dari nilai keseharian siswa dlaam belajar, ibadah, dan akhlak.

\section{PEMBAHASAN}

Hasil penelitian ini menyajikan potret yang menarik mengenai konsep integrasi kurikulum dan hasil dari strategi mengintegrasikan kurikulum. Dalam pembahasan ini akan dibagi menjadi beberapapoin meliputi: Pertama, konsep integrasi kurikulum antara lain adanya keterpaduan mata pelajaran di pondok dengan sekolah. Seperti mata pelajaran Nahwu, pelajaran Sorof itu di masukkan kedalam kurikulum sekolah. Konsep kegiatan yang dilakukan siswa dan juga pada pendekatan. Pembiasaan adanya syawir, hafalan imriti, hafalan yasin dan tahlil. Kedua, hasil dari integrasi kurikulum telah cukup terlihat dari Strategi mengintegrasikan kurikulum di SMP Mambaus Sholihin telah cukup terlihat dari output atau lulusan peserta didiknya. Tampak sekali kemampuan yang diperoleh siswa-siswa SMP Mambaus Sholihin dalam beragam perlombaan. Kemampuan yang diperoleh baik kemampuan akademik maupun kemampuan non akademik. Siswa-siswi kelas IX diwajibkan hafal imriti sebagai syarat kelulusannya.

Istilah strategi berasal dari bahasa yunani 'stratogos' yang berarti jendral atau panglima sehingga strategi diartikan ilmu kejendralan/ panglimaan, pengertian strategi dalam dunia pendidikan menurut ekslopedi pendidikan strategi adalah the art bringing force to the battle field vaforabel position dalam pengertian ini strategi adalah suatu membawa pasukan kedalam medan pertempuran dalam posisi yang menguntungkan. Strategi juga dapat diartikan sebagai a plan operation a ceaving same thing yaitu rencana kegiatan untuk mencapai sesuatu (W. Ceulo, 2002)

S. Nasution dalam bukunya "asas- asas kurikulum" mengatakan integrasi berasal dari kata "integer" yang berarti keseluruhan (S. Nasution, 2006). Freire mengemukakan sebagaimanatrt yang dikutip oleh Andi Haris Prabawa, dalam buku " pradigma pengembangan kurikulum pendidikan tinggi tahun 2000" integrasi adalah kemampuan menyesuikan dengan realitas (Andi Haris Prabawa, 2002).

Hasil penelitian ini menyajikan potret yang menarik mengenai strategi mengintegrasika kurikulum pondok dan sekolah dalam meningkatkan prestasi siswa SMP Mambaus Sholihin. Dalam pembahasan ini akan dibagi menjadi beberapa poin meliputi konsep mengintegrasikan Kurikulum Pondok Pesantren dan Sekolah, serta hasil dari integrasi kurikulum.

Pada konsep intergrasi kurikulum, secara global guru menyusun RPP (Rencana perlaksanaan Pembelajaran), disesuaikan dengan ketentuan pemerintah yaitu dengan standar K-13 (Kurikulum 2013), kemudian guru mengembangkan kurikulum tersebut menjadi RPP pelaksanaan harian serta menjadikannya sebagai

366 BRILIANT: Jurnal Riset dan Konseptual

Volume 5 Nomor 2, Mei 2020 
dasar dalam menentukan metode yang akan digunakan guru dalam proses pembelajaran.

Kegiatan menerjemahkan kurikulum yang dilakukan guru serta menjadikannya sebagai pedoman dalam penyelenggaraan kegiatan belajar mengajar dan menjadikannya program pembelajaran merupakan pengertian dari Perencanaan pembelajaran (Wina Sanjaya, 2011). Hal ini disampaikan oleh Beane James yang dikutip oleh Agus Zaenul Fitri, bahwa perencanaan kurikulum merupakan suatu proses yang melibatkan berbagai unsur peserta dalam banyaknya tingkatan, membuat keputusan tentang tujuan belajar, cara mencapai tujuan situasi belajar-mengajar, serta menelaah keefektifan dan kebermaknaan metode tersebut. Sehingga sistematika berbagai pengalaman belajar tidak akan saling berhubungan dan mengarah pada tujuan yang diharapkan tanpa perencanaan dalam kurikulum (Agus Zaenul Fitri, 2013).

Guru menggunakan Rencana Pelaksanaan Pembelajaran (RPP) dan Silabus dalam pembelajarannya, dalam menyusun Silabus dan RPP guru berpedoman pada Standar Isi. Perencanaan yang diperlukan dalam pembelajaran diantaranya sumber belajar, penyusunan RPP, skenario pembelajaran dan penyiapan media serta perangkat penilaian pembelajaran. Pendekatan yang dipakai dalam pembelajaran yang dipakai harus sesuai dengan RPP dan Silabus (Pengaturan Menteri Pendidikan dan Kebudayaan Republik Indonesia, 2013).

Hasil integrasi kurikulum dilakukan dengan evaluasi pembelajaran. Guru dan Kepala Sekolah melaksanakan evaluasi pembelajaran. Pada saat pemberian materi pembelajaran terhadap siswa itu bentuk evaluasi yang dilakukan oleh guru. Sedangkan terkait dengan kinerja guru dalam melakukan proses belajar mengajar itu bentuk evaluasi yang dilakukan oleh Kepala Sekolah. Kepala Sekolah melakukan evaluasi setiap semester dua kali dengan cara melakukan supervisi dengan maksud untuk melihat persiapan guru sebelum mengajar. Evaluasi merupakan kegiatan yang harus dilakukan guru supaya tahu apakah tujuan yang ditentukan bisa tercapai, dan setelah di laksanakannya program. Tersebut apa dampaknya. Evaluasi merupakan kegiatan mengumpulkan, memilih, menganalisis, serta menyajikan informasi yang bisa dipakai dan dijadikan pedoman dalam mengambil keputusan serta menyusun program berikutnya (S. Eko Putro Widoyoko, 2009). Evaluasi pembelajaran dilakukan oleh seluruh Pamong pondok pesantren adalah semua pamong pondok pesantren menyerahkan hasil evaluasi tersebut ke BK dari seluruh pondok pesantren. Jadi BK inilah sentral dari semua evaluasi yang telah dilakukan. Guru BK tidak menjadi pamong pondok pesantren, karena BK merupakan bimbingan untuk seluruh siswa di dalam pondok pesantren maupun di dalam sekolah. Jadi untuk BK 24 jam. Hasil evaluasi tersebut dilaporkan kepada guru BK, pamong pondok pesantren, wali kelas, dan pimpinan terkait hasil penilaian tersebut.

\section{KESIMPULAN}

Konsep integrasi kurikulum ini, terdapat tahap perecanaan. Guru menyusun RPP (Rencana Pelaksanaan Pembelajaran) disesuaikan sesuai standar K-13 (Kurikulum 2013), selanjutnya guru mengembangkannya menjadi RPP yang digunakan sebagai dasar dalam 4melaksanakan proses belajar mengajar. 34Sedangkan pembelajaran di pondok pesantren. Pamong pondok pesantren hanya 
menjabarkan secara kreatif, tidak menyusun RPP, karena materi pembelajaran di pondok pesantren 9dan di sekolah tersebut sama.

Hasil integrasi kurikulum melalui tahapan. Guru, pamong pondok pesantren, serta Kepala Sekolah melaksanakan evaluasi pembelajaran. Tugas evaluasi pembelajaran yang dilaksanakan guru meliputi evaluasi kognitif, afektif serta psikomotorik. Sedangkan pamong asrama, melaksanakan evaluasi afektif bukan kognitif. Tugas evaluasi kepala sekolah adalah menilai kinerja kerja guru selama guru melakukan proses pembelajaran.

\section{SARAN}

Berdasarkan hasil simpulan yang ada makat terdapat beberapa langkah tindak lanjut yang dapat dilakukan untuk memperbaiki kondisi permasalahan yang ada. Pertama, Dalam pembelajaran, hendaknya guru menekankan pada kesabaran dan ketelatenan dalam menyampaikan materi. Selain itu, guru juga harus menanamkan sikap kedisiplinan terhadap siswa. Kedua. Melakukan penelitian tindak lanjut terutama berkaitan integrasi kurikulum pondok pesantren dan sekolah dalam meningkatkanprestasi siswa yang lain, baik pada sekolah umum maupun madrasah.Hal ini perlu dilakukan sebagai kekuatan dan strategi dalam mengembangkan integrasi kurikulum pondok pesantren dan sekolah.

\section{DAFTAR RUJUKAN}

Alim, Muhammad. 2006. Pendidikan Agama Islam, upaya pembentukan pemikiran dan kepribadian Muslim. Bandung: Rosda.

Hendriyenti. "Pelaksanaan Program Boarding School dalam Pembinaan Moral Siswa Di SMA Taruna Indonesia Palembang" dalam Ta'dib, Vol. XIX, No.60, Edisi November.

Koesoema A, Donie. 2007. Pendidikan Karakter. Jakarta: Grasindo.

Mansur, Hasan. Metode Islam dalam Mendidik Remaja (Judul Asli Manhajul Islam fi Tarbiyyatis-Syabab). Jakarta Selatan: Mustaqim.

Sanjaya, Wina. 2011. Perencanaan dan Desain Sisitem Pembelajaran. Jakarta: Kencana.

Widoyoko, S. Eko Putro. 2009. Evaluasi Program Pembelajaran. Yogyakarta: Pustaka Pelajar.

Zaenul Fitri, Agus. 2013. Manajemen Kurikulum Pendidikan Islam dari NormatifFilosofis. Bandung: Alfabeta.

Ceulo W. 2002. Stategi Belajar Mengajar. Jakarta: PT Grasindo.

Haris Prabawa, Andi. 2002. Pradigma Pengembangan Kurikulum Pendidikan Tinggi. Muhammadiyah Universitas Press.

Nasution S. 2006. Asas-Asas Kurikulum. Jakarta: Bumi Aksara. 